\title{
What is innovative to public libraries in the United States? A perspective of library administrators for classifying innovations
}

\author{
By: Devendra Potnis, Ph.D. \\ Joseph Winberry \\ Bonnie Finn \\ Courtney Hunt
}

\begin{abstract}
Innovations are critical for public libraries but rarely any primary research studies the scope and interpretation of the term "innovation" by public libraries. Also, few of the existing innovation typologies are based on data collected from public libraries. This study fills in the gap by eliciting 80 innovations reported by the administrators of 108, award-winning public libraries in the United States, and proposes the first organic classification of innovations for public libraries, with the following four types of innovations: Program (access-oriented/useoriented), Process (efficiency-driven/effectiveness-driven), Partnership (internal/external), and Technology (web-based technologies/assistive technologies/artificial intelligence). Findings can advance the state of innovations in libraries.
\end{abstract}

Keywords: Innovation, Public libraries, Program, Process, Technology, and Partnership

\section{Introduction}

Innovation is defined as "the introduction of novelties; the alteration of what is established by the introduction of new elements or forms (Oxford English Dictionary Online, 2018)."

Joseph Schumpeter, who is frequently referred to as the godfather of innovation studies, argues that an innovation is a process that any organization needs to revisit and manage constantly in order to retain the strategic advantage created by the innovation (Schumpeter, 1939). Dain (1972) and Jenkins (1990) define innovation as a vision of continuous change 
and operationalize the definition for public libraries as an opportunity for improving themselves and their surroundings. Anderson (2003) characterizes innovation as any change or adaptation that enhances the value of public libraries for their stakeholders. A multidisciplinary study conceptualizes innovation as "the multi-stage process whereby organizations transform ideas into new or improved products, service or processes, in order to advance, compete and differentiate themselves successfully in their marketplace (Baregheh, Rowley, and Sambrook 2009: 14)." The innovation management framework defines and measures any innovation in terms of the exploitation of inputs, knowledge management, strategy, organizational culture, portfolio management, project management, and commercialization for implementing new ideas (Potnis, 2010). In establishing the Journal of Library Innovation, Sheryl Knab acknowledged the challenges surrounding the word "innovation" in related research, stating that, "Not only does the journal fit a niche in the field, but also it may very well define what innovation is for libraries (2010, p. 4)." Skinner (2017) conceptualizes the term innovation as an internally motivated and proactive approach to change, whereas Civitello (2017) describes innovation as a natural response of public libraries to their daily problems. Thus, there is no agreement among scholars about the definition and scope of the term innovation.

A similar trend is observed in practice. For instance, it is not clear what is considered innovative by public libraries. A majority of studies suggest that innovations in public libraries comprise of access to information, technology, services, support, and expertise for better serving patrons and diverse communities (Gorham and Bertot, 2018). As part of the innovative initiatives, a large number of public libraries primarily focus on providing access to information, technology, and expert guidance on different topics, and helping patrons 
build skills for using information, technology, and expert guidance offered by the libraries (Mathews, 2012).

Innovations play a significant role for public libraries and their patrons. For instance, in the era of scarce resources and budget cuts, innovations are critical for the relevance of over 9,000 public libraries with over 17,000 branches across the United States (Sin and Vakkari, 2015), especially since innovations can help public libraries better engage with patrons and justify more funding for expanding services and products (Evjen, 2015). Innovations can also help public libraries challenge the status quo and therefore increase their value for local communities (Skinner, 2017). For instance, innovations serve as a means for public libraries to address the needs and challenges related to but not limited to economic development, poverty, education, health, transportation, and environment, which are faced by library patrons and local communities (Bertot, Jaeger, Lee, Dubbles, McDermott, and Real, 2014). As a result, public libraries can serve as anchors for the communities they serve. Innovations help public libraries generate positive socio-economic outcomes and lifelong learning for their patrons, communities, and other stakeholders (Field and Tran 2018). Innovations also seem like an opportunity for public libraries to reposition themselves for better adaptation to the changing needs and priorities of communities. Innovations, in general, support the inclusion of new ideas essential to a library's future, rather than defaulting to a passive response to change in society (Evans, Ward, and Rugaas, 2000). Innovations can also help public libraries serve diverse populations better (Cooke, 2017). Finally, innovations can make public libraries more competitive with benefits including but not limited to attracting and retaining patrons, seeking more funding, and enhancing the perceived image of libraries (Knab, 2010).

\section{Research question}


In the context of the significance of innovations for public libraries and their patrons, and the varying understanding and scope of the term innovation proposed by past research, we propose and study the following research question: "What is considered innovative by public libraries?

We approach this question from the library administrator point of view because the ability of leaders to encourage, plan, and implement innovations in any organization is at the heart of planning, implementing, and sustaining innovations (Bossaller, Adkins, and Brendler, 2017; Damanpour and Schneider, 2008). Innovation is an inherently risky process; hence, administrators should develop a risk-tolerant culture in libraries so that librarians would dare to experiment and not be afraid of failure (Farkas, 2010). Administrators are also responsible for successfully introducing change in their libraries, including developing an attitude among librarians that change is the new stability for libraries (Carpenter and Green, 2009). King (2018) offers a specific guidance to library administrators for developing a systematic plan to implement innovations, which includes (a) scanning the environment for becoming aware of the current trends in innovations implemented by peers, (b) making sense of the contemporary innovations implemented by early adopters, and (c) assessing if contemporary innovations are applicable and have the potential to advance the mission and goals of a specific library. Public libraries, whose leaders are unable to make sense of the internal and external environment, are less likely to be able to manage innovations in libraries (Baker, 2004; Rowley, 2011; Pulido and Vivarelli, 2016). In a similar vein, after interviewing directors of 15 public libraries, Freeburg (2018) found that leadership styles affect the type of innovations implemented in public libraries. Thus, administrators play a critical role in planning and implementing innovations in public libraries, but rarely does any study show what is considered innovative by them. We fill in this gap. 


\section{Types of innovations in organizations}

Business scholars spearheaded the research on classifying innovations in organizations. Robertson (1967) classified organizational innovations as continuous innovations (i.e., improving existing products or services), dynamically continuous innovations (i.e., creating new products or services or altering existing products or services), and discontinuous innovations (i.e., establishing new products or services and new behavior patterns of customers). However, this approach was criticized for the overlap between the three types of innovations. For instance, continuous innovations could be a subset of dynamically continuous innovations in organizations. Dewar and Dutton (1986) addressed this drawback by proposing the classification of innovations based on the levels of newness (e.g., radical innovation vs. incremental innovation) and on the outcome of an innovation (e.g., external/tangible innovation vs. internal/intangible innovation).

Based on his business consultancy experience and research with businesses, Moore (2008) proposed 12 distinct types of innovations by businesses and categorizes them into four innovation zones: product leadership zone, customer intimacy zone, operational excellence zone, and category renewal zone. However, this classification is too complicated and might not be applicable to businesses representing various types of industries. In response to the call for a more generalized framework for classifying innovations, Tidd, Bessant, and Pavitt (2013) proposed the following four types of innovations: "(a) product innovation (i.e., changes in the things (products/services) which an organization offers, (b) process innovation (i.e., ways in which they are created and delivered), (c) position innovation (i.e., changes in the context in which the products/services are introduced), and (d) paradigm innovation (i.e., changes in the underlying mental models which frame what the organization does)(p. 10).” 
This evolution in classification of innovations suggests that it is grounded in the research and practice related to businesses with "profit making" as the bottom-line; as a result, this classification of innovations cannot be applied "as is" by public libraries, which are not-for-profit organizations. There needs to be an organic schema of innovations to help administrators better manage innovations in libraries. The innovation-type mapping tool (Rowley, Baregheh, and Sambrook, 2011) serves as a good starting point since it integrates a range of frameworks on types of innovations, but it is grounded mainly in the business literature on innovations and is also not customized using contemporary innovations in public libraries.

Although libraries implement innovations that vary considerably in their scale, associated resource implications, and strategic impact, there is little evidence of discussion of types of innovations in the library management literature (Rowley 2011). "Innovation and the Library: The Adoption of New Ideas in Public Libraries" by Pungitore (1995) serves as a milestone for guiding public libraries to implement innovations. It identifies major events, trends, and historical patterns in the diffusion of various innovations in public libraries from the early 1960s to 1979 and provides mechanisms to improve the process of introducing innovations in public libraries. However, this "one-size-fits-all” guidance does not distinguish between different types of innovations that could possibly co-exist in public libraries nor does it take into account the different ways in which libraries need to manage these innovations. The existing classification of innovations in libraries is not comprehensive and does not cover all types of innovations in libraries (Jantz, 2012a). For instance, one of the most widely used classifications of innovations in libraries focuses on the following four types of innovations: revolutionary innovation (where technology and markets are new), radical innovation (where the technology is new but the markets are the same), market niche 
(where the technology is not new but it is applied to a new markets), and regular innovation (which represents the evolution in the existing technology for the existing market) (Baker 2004). However, innovation can be a new idea, concept, product, system, or service related to library and information provision (Baker, 2014). Therefore, innovation in libraries is not necessarily limited to technology implementation. Hence, Baker's (2004) classification of innovations might not be applicable "as is" to non-technological innovations in libraries. If the word technology is replaced by innovation, Baker's schema of innovations could serve as a useful starting point for understanding library innovations. Vassilakaki (2015) discusses service innovations in public libraries, but again the main focus remains on technologyrelated digital media collections and Internet of Things.

Osborne (1998) proposed the following classification of innovations in voluntary and community organizations: total innovation (i.e., providing new services to new patrons), expansionary innovation (i.e., serving new patrons with existing services), evolutionary innovation (i.e., providing new services to the same patrons), and incremental development (i.e., providing incrementally improving services to same patrons). This classification schema and its minor variations (Osborne, Chew, and McLaughlin, 2008) are useful in classifying innovations in public libraries but such classification schemas are neither grounded nor validated using contemporary innovations in libraries.

Rubin, Gavin, and Kamal (2011) respond to Knab’s (2010) appeal to define the term innovation for librarianship by reviewing the literature on innovation and the description of library services on publicly accessible websites of 160 public and academic libraries in North America. Their secondary research identified the following ten areas of innovation in libraries: technology, service, culture, vague, character, use, program, facility, resource, and partnership. However, two major limitations of this study limit the utility of findings. Firstly, 
the ten areas of innovation are not mutually exclusive; there is a considerable overlap among these areas of innovation (e.g., service and program, facility and resource, etc.). Secondly, Rubin, Gavin, and Kamal (2011) acknowledge that their study does not cover "backend" innovations such as staff reorganizations, which are typically not broadcast on the websites of the libraries studied. In contrast, our study proposes mutually exclusive categories of innovations based on the responses collected from library administrators.

Jantz (2012b) also partially fills in the gap in the secondary research by Rubin, Gavin, and Kamal (2011). Based on the in-depth interviews with six librarians in university libraries, Jantz (2012b) classifies innovations in libraries as technical and administrative innovation with associated attributes like product and process. This classification is similar to the innovation taxonomy proposed by organizational theorists (e.g., Damanpour, 1996; Daft and Becker, 1978). Sample technical products identified by Jantz (2012b) include institutional repositories, e-Books, streaming videos to classrooms, etc. Creating new library services, leasing library space, mass digitization, and providing technical services to faculty, staff, and students represented some of the technical processes identified in his study, whereas administrative processes involved budgeting, planning new business processes, and revenue generation. There were no administrative products reported by his study. Table I summarizes the classes found in earlier innovation schemes.

Table I. Existing Classifications of Innovations in Organizations

1 A. Continuous innovations, improving existing Robertson, 1967 products or services

B. Dynamically continuous innovations, creating new products or services or altering existing products or services 
C. Discontinuous innovations, establishing new products or services and new behavior patterns of customers

2 A. Radical innovation

B. Incremental innovation

C. External/tangible innovation

D. Internal/intangible innovation

312 distinct types of innovations by businesses and categorized into four innovation zones:

A. Product leadership zone

B. Customer intimacy zone

C. Operational excellence zone

D. Category renewal zone

4 A. Product innovation, changes in the things (products/services) which an organization offers

B. Process innovation, ways in which they are created and delivered

C. Position innovation, changes in the context in which the products/services are introduced

D. Paradigm innovation, changes in the underlying mental models which frame what the organization does

5 The innovation-type mapping tool serves as a good starting point for innovations in libraries since it integrates a range of frameworks on types of innovations, but it is grounded mainly in the business literature on innovations and is also not customized using contemporary innovations in public libraries.

6 A. Revolutionary innovation, where technology and markets are new

B. Radical innovation, where the technology is new, but the markets are the same

C. Market niche, where the technology is not new, but it is applied to new markets

D. Regular innovation, which represents the evolution in the existing technology for the existing market

7 A. Total innovation, providing new services to new patrons

B. Expansionary innovation, serving new patrons with existing services

C. Evolutionary innovation, providing new services to the same patrons
Dewar and Dutton, 1986

Moore, 2008

Tidd, Bessant, and Pavitt, 2013
Baregheh, Rowley, and Sambrook, 2009

Baker, 2004
Osborne, 1998 
D. Incremental development, providing incrementally improving services to same patrons

Areas of innovation in libraries

Rubin, Gavin, and Kamal, 2011

A. Technology: Specific hardware or software

B. Service: Reference or instructional service

C. Culture: Identity or brand

D. Vague: Subject of innovation cannot be identified

E. Character: Human resources

F. Use: Ways in which users interact with materials

G. Program: Special activities

H. Resource: Physical space of libraries

I. Partnership: Internal and external collaboration between libraries and their stakeholders

9 A. Technical innovation

Damanpour, 1996; Deft and Becker,

B. Administrative innovation 1978; Jantz 2012b

10 Miscellaneous innovations (tested in libraries)

A. Open innovation

Henkel, Ilhan, Mainka, and Stock, 2018

B. Collaborative innovation

C. Service innovation

Rowley, 2011

Goulding and Walton, 2014

D. Disruptive innovation

Yeh and Walter, 2017

The above table shows that most of the schemas and typologies proposed for classifying innovations in organizations are informed by evolving theories and practices in business, management, and marketing. The degree of change (i.e., continuous, disruptive, dynamically continuous, incremental, radical, revolutionary), functional areas and operands in organizations (e.g., technical, administrative, program, resources), offerings (e.g., service, product), and the type of implementation (e.g., open, collaborative, continuous, discontinuous) are some of the key categories of innovations (see Figure I). The categorization of types of innovations is based on the definitions of these innovations grounded in the past research. We do not claim it to be exhaustive but a representative sample of innovations in organizations. 
Figure I. Types of Innovations

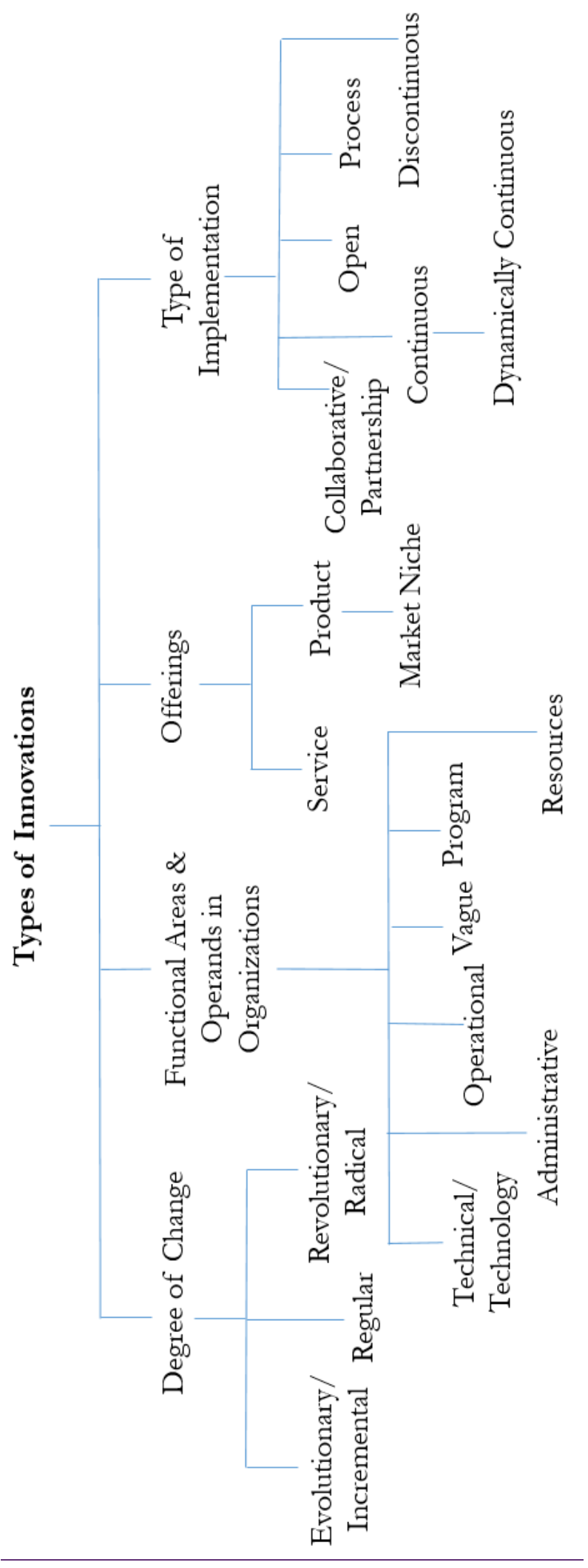


There is rarely any classification of innovations proposed using empirical research on innovations in libraries or grounded in the library science literature. There are significant contextual differences in terms of strengths, opportunities, weaknesses, and threats experienced by academic, public, special, and school libraries (Brundy, 2015). For instance, the markets referred to by Baker (2004) in his schema of innovations are significantly different for different types of libraries. Academic libraries have different type and level of access to the market resources required to plan and implement innovations than that of public libraries. Also, the unique place that public libraries hold in society civically and in between the public and private sectors, suggests that classifications from other private and voluntary organizations, and even classifications from academic libraries, will not take into account the specific needs of public libraries (Widdersheim, 2015; Koizumi and Widdersheim, 2016). This existing research dearth tacitly reinforces the misconceived idea that public libraries cannot innovate to meet the ever-evolving needs of society and must be responded to.

A majority of library and information science (LIS) researchers employing the preexisting classifications of innovations, which are grounded mainly in the business and management literature, validate them in the context of libraries. For instance, Jantz (2013) tests incremental vs. radical innovations (Nadler and Tushman, 1990) and technical vs. administrative innovations (Damanpour, 1987) using data collected from academic and research libraries. Theoretical concepts and frameworks related to open innovation (Henkel, Ilhan, Mainka, and Stock, 2018), collaborative innovation (Rowley, 2011), service innovation (Goulding and Walter, 2014), and disruptive innovation (Yeh and Walter, 2017) are tested by LIS researchers in academic and public libraries in the US and abroad. However, we could not find a single study that proposes innovation typology using data collected from public 
library staff. Hence, we argue that there needs to be an organic classification of innovations in public libraries for helping administrators of public libraries make sense of the environmental scan and prioritize the allocation of limited resources when crafting strategies for managing innovations.

\section{Methods}

This paper is part of a larger study conducted with winners of the Urban Libraries Council's Top-Innovators Award from 2009 to 2016. Urban Library Council is the "premier membership organization of North America’s leading public library systems (Urban Libraries Council, 2018: 1).” Every year the council recognizes initiatives with the Top-Innovators Award, which "showcase out-of-box thinking and new alignment of resources to further education for people of all ages, address race and social equity in... communities, build digital inclusion and literacy, and enhance civic engagement for strong democracy (Urban Libraries Council, 2018)."

In the first stage, we emailed an online survey designed using Qualtrics to 219 administrators of these award-winning libraries to learn about the top-3 innovations in their organizations. We received 108 total responses, with a response rate of $49.3 \%$. The survey asked them to report the top-3 innovations in their library which they are proud of. Some of them reported less than three innovations, resulting in overall 80 distinct innovations.

In the second stage, we visited websites of these 80 innovations and collected details such as the goal, populations served, and implementation details of these innovations. Specific names of innovations provided by the respondents facilitated our search process and helped us confirm the offerings of these innovations. We anonymized the innovation names in the finding sections in accordance with what was promised to survey participants. 
In the third stage, two researchers coded the 80 innovations based on the information found about these innovations on public library websites. Coding is a popular technique for analyzing qualitative data, especially for identifying patterns in qualitative responses (Auerbach and Silverstein, 2003). Based on the literature on organizational innovation, we developed a set of criteria for categorizing innovations. We labelled an innovative initiative as Program innovation when it (a) requires initial and/or recurring investment, (b) has a budget which might need to be justified periodically, (c) uses human resources, and (d) caters to a specific population to meet their needs (Thorpe, 2017). For instance, after visiting the website of a Home Delivery Program, which was one of the distinct reported innovations, we confirmed that it required the concerned library to invest in it; it has a budget; it uses a combination of volunteers and librarians; and it aims to meet the needs of specific populations such as homebound, older adults.. Hence, we labelled it as a Program innovation. Similarly, we marked an innovation as Process innovation when it encompasses a set of evolving actions or procedures with which libraries perform essential services, defining how they conduct business effectively with their patrons (Stejskal and Hajek, 2015; Matthews, 2017). This coding process helped us identify the types of innovations implemented in public libraries in the United States.

The disparities in coders in terms of their academic backgrounds (e.g., information sciences and history vs. public administration and computer science), work experiences (e.g., not-for-profit organizations vs. academic institutions), and attitudes toward this research topic (e.g., innovations for serving disadvantaged communities vs. innovations for creating competitive advantages for public libraries) led to rigorous data analysis. The inter-coder agreement for coding was above $90 \%$. We adopted negotiated agreement approach for reconciling the differences in our codes (Campbell, Quincy, Osserman, and Pedersen, 2013). 
In particular, we explained the differences in codes using our interpretations. We soon realized that our interpretations differed due to the varying degree of academic backgrounds, work experiences and attitudes toward this research topic. We explained and clarified the differences in our interpretations, which helped us reconcile our differences in codes.

\section{Findings}

We classified distinct innovations reported by library administrators into the following four categories: Program, Process, Partnership, and Technology (see Table II). None of the innovations belongs to more than one category. We made sure to anonymize the innovations by generalizing their labels so that respondents and the innovations in their public libraries are unidentifiable.

Table II. Proposed Classification of Innovations in Public Libraries

\begin{tabular}{|c|c|c|c|}
\hline $\begin{array}{c}\text { Types } \\
\text { of } \\
\text { Innovations } \\
\end{array}$ & $\begin{array}{c}\text { Sub- } \\
\text { Categories }\end{array}$ & Main Goal/ Scope & $\begin{array}{c}\text { Sample Innovations } \\
\text { Reported by Respondents }\end{array}$ \\
\hline \multirow[t]{2}{*}{ Program } & $\begin{array}{l}\text { Access- } \\
\text { Oriented }\end{array}$ & $\begin{array}{l}\text { To avail access to } \\
\text { services, facilities, } \\
\text { and products }\end{array}$ & $\begin{array}{ll}\text { 1. } & \text { Home Delivery } \\
\text { Program } \\
\text { 2. Small Business Service } \\
\text { 3. } \\
\text { 4. } & \text { Civil Discourse } \\
& \text { Program }\end{array}$ \\
\hline & Use-Oriented & $\begin{array}{l}\text { To ensure use of } \\
\text { services, facilities, } \\
\text { and information } \\
\text { products }\end{array}$ & $\begin{array}{ll}\text { 5. } & \text { Collaborative } \\
\text { Technology Center } \\
\text { 6. Storytelling Program } \\
\text { 7. Literacy Center for } \\
\text { Cooking }\end{array}$ \\
\hline \multirow[t]{2}{*}{ Process } & $\begin{array}{l}\text { Efficiency- } \\
\text { driven }\end{array}$ & $\begin{array}{l}\text { To generate } \\
\text { efficiency in the } \\
\text { existing processes }\end{array}$ & $\begin{array}{l}\text { 8. New Professional } \\
\text { Structure } \\
\text { 9. Streamlined Processing } \\
\text { 10. New Application of } \\
\text { Exhibit Spaces } \\
\text { 11. Stress Test } \\
\end{array}$ \\
\hline & $\begin{array}{l}\text { Effectiveness- } \\
\text { driven }\end{array}$ & $\begin{array}{l}\text { To design more } \\
\text { effective processes }\end{array}$ & $\begin{array}{l}\text { 12. Building Diverse Teams } \\
\text { 13. Employing Social } \\
\text { Workers } \\
\text { 14. Public Librarian }\end{array}$ \\
\hline
\end{tabular}


Liaisons

\begin{tabular}{|c|c|c|c|}
\hline & & & Liaisons \\
\hline \multirow[t]{2}{*}{ Partnership } & Internal & $\begin{array}{l}\text { To form novel } \\
\text { combinations of } \\
\text { teams of } \\
\text { employees }\end{array}$ & 15. Makerspace Task Force \\
\hline & External & $\begin{array}{l}\text { To collaborate } \\
\text { with external } \\
\text { partners and } \\
\text { communities }\end{array}$ & $\begin{array}{l}\text { 16. College/Public Library } \\
\text { Shared Campus } \\
\text { Partnership } \\
\text { 17. Neighborhood Research } \\
\text { Service } \\
\text { 18. Community Writing } \\
\text { Project } \\
\text { 19. School Access Program } \\
\text { 20. Digital Inclusion Week }\end{array}$ \\
\hline \multirow[t]{3}{*}{ Technology } & $\begin{array}{l}\text { Web-based } \\
\text { Technologies }\end{array}$ & $\begin{array}{l}\text { Internet-based } \\
\text { technologies }\end{array}$ & 21. Google Chromebooks \\
\hline & $\begin{array}{l}\text { Assistive } \\
\text { Technologies }\end{array}$ & $\begin{array}{l}\text { Technologies for } \\
\text { disabled patron }\end{array}$ & 22. Reading Machines \\
\hline & $\begin{array}{l}\text { Artificial } \\
\text { Intelligence }\end{array}$ & $\begin{array}{l}\text { Machine learning and } \\
\text { computing }\end{array}$ & 23. Robots \\
\hline
\end{tabular}

\section{Program innovations}

We define "Program" innovation as a new initiative designed and implemented for catering to the needs of a specific patron population. Public libraries implement a wide range of business models (e.g., subscription-based vs. free service) for rolling out innovations. We identified two subcategories of the Program innovations, in terms of access and use, which represent the two primary goals of these innovations.

Access-oriented Program innovations provide access to a wide range of new services and products to new or existing groups of patrons such as immigrants, aging population, patrons with disabilities, and autistic children, among others, therefore promoting diversity and multiculturalism in public libraries. Sample services include the delivery of library material, providing access to library space and information resources, availing timely 
assistance and guidance, and providing equity of access to populations that have been historically disadvantaged. Sample innovations are as follows.

1. Home Delivery Program: A public library delivers books, films, and digital material like CDs to the homes of patrons who have difficulties getting to their local public library. In an age when patrons can have groceries delivered to your house, this public library decided to deliver library products. The home delivery service also engages homebound patrons such as older adults or people with disabilities with the resources of their local public library. This service (a) better integrates the homebound into the community, (b) lessens their loneliness, and (c) puts a pair of eyes on someone who might otherwise be completely without contact.

2. Small Business Service: Libraries help entrepreneurs in the beginning stages of their business with the hopes that early planning prevents larger problems that can come up later. Some of the services provided include helping people move from the idea to the action stage where components such as accounting, customer service, and inventory come into play. Also, this service supports business scaling where people are encouraged to try a smaller version of their entrepreneurial dreams to minimize financial and opportunity consequences. Many public libraries provide business and nonprofit-specific reference work, but entrepreneurial support is an innovative approach to this work.

3. Youth Fines Removal: Some public libraries are involved in the social justice work of providing equity of access for populations who have been historically disadvantaged. The library decides to do away with youth fines because they realize that a child's earliest years are some of the most developmentally important. Late return fines are often a true barrier that prevents some children from being able to have regular 
access to library services (American Library Association, 2001; Conway 2005). A lack of library services can mean a lack of multimedia resources for children. Removing the fines helps remove barriers, helps to ensure access, and works towards social justice for people who might not otherwise enjoy the access that wealthier patrons could afford.

4. Civil Discourse Program: This program was started in the wake of the shooting of Congresswoman Gabrielle Giffords and 18 others, which occurred during a constituent event. This program advocates for a return to civility in political discourse and action. Similar programs have been started around the country. Many types of organizations such as public libraries are encouraged to offer civil discourse programs which provide moderated forums and venues for people to engage respectfully on issues of politics.

As part of the use-oriented Program innovations, librarians offer demonstrations or train patrons for using third-party resources like software tools, technical training modules, expert guidance on cooking, storytelling, for developing different types of skills such as digital literacy, information literacy, storytelling, and coding, among others. One or more respondents reported the following examples.

5. Collaborative Technology Center: It offers large-scale technology training, open and available to the public. It involved training patrons to use productivity software like Adobe, robotics, studio software for audio-video recording, etc.

6. Storytelling Program: The Storytelling Program certifies people as storytellers through a program that builds both oral and written storyteller skills that could help them succeed in their personal and professional lives. Some public libraries have resident storytellers, hence folklore, storytelling, and similar skills are kept alive and 
displayed prominently to their communities, while some storytelling programs are working to be accessible to those with disabilities such as autism.

7. Literacy Center for Cooking: It is a teaching kitchen that bridges literacy and food by strengthening people's knowledge of and relation to food. This is accomplished through demonstrations of making culturally-specific foods, seed swaps where people can access new and different plants and vegetables, and classes that work to teach people with intellectual disabilities how to prepare food for themselves. A few public libraries around the country have been identified as providing similar services, including libraries with a mobile kitchen.

\section{Process innovations}

An innovative process reflects a set of actions and procedures with the involvement of multiple actors (Baker, 2014). We define "Process" innovation as a novel combination of actions, routines, or procedures for serving patrons. Process innovations are implemented mainly for creating effectiveness (i.e., doing right things) and efficiency (i.e., doing things right) in public libraries.

Efficiency-driven Process innovations are primarily internal in nature and involve new services and mechanisms for enhancing capabilities of internal actors like librarians, library spaces, and library administrators. The following innovations are reported by one or more respondents.

8. New Professional Structure: A new professional structure is introduced in some libraries. In this model, each reference librarian is dedicated to a specific literacy, partnering, programming, or collections expertise. Some public libraries realign their library staff to meet the specific needs of their constituents. This innovation highlights the significance of recruiting library and information science graduates 
working in the libraries and helps public libraries create innovative roles that are designed to meet the specific needs of the community they serve.

9. Streamlined Processing: Streamlined processing of new materials in a single location reduces backlog, establishes a 24-48 hour turnaround time for new materials, and centralizes selection and distribution of the collections, thereby speeding up the process of cataloging. This process makes it easier to intake new materials, prepare them for distribution, and put the new materials into the hands of patrons. This process saves time and money and lessens frustration with anticipating patrons. It also makes it easier to clear out existing materials so that they can float between branches or be removed from the library entirely.

10. New Application of Exhibit Spaces: Several libraries have exhibit spaces. A public library in the Midwest uses its exhibit space for unconventional purposes, encouraging patrons to experiment and play with the different pieces of the exhibit.

11. Stress Test: Designed as an internal assessment tool, the stress test acknowledges the necessity for libraries to adapt to modern needs without abandoning their core mission and services. A major public urban library designed this internal assessment to see how impactful, feasible, viable, and sustainable programs and services are in the modern, forever shifting world.

Effectiveness-driven Process innovations aim to improve existing services for better serving the same patrons. Examples reported by one or more respondents are as follows.

12. Building Diverse Teams: This program recruits librarians from diverse backgrounds to represent and better serve patrons with differences such as age, gender, sexual orientation, ethnicity, socio-economic status, physical ability, nationality, legal status, 
and other diverse perspectives. The teams are designed with the intention of representing the diversity reflected within the community they serve.

13. Employing Social Workers: Over the past several years, the line between librarianship and social work has blurred as many regular library patrons have needs that require additional assistance beyond more traditional library work. Employing social workers in libraries lets people get help where they are and builds on existing relationships to assist patrons.

14. Public Librarian Liaisons: Public librarians with knowledge in particular subject areas help patrons find information resources like books, CDs, etc. This innovation allows interested patrons to reach out to librarians with specific foci and expertise. For instance, if the patron is looking for romance novels, the patron is able to consult with a librarian who specializes in the subject. If the patron would like a good mystery or a biography, there are librarians who focus on this and could help find something that fits well with the patron's interests.

\section{Partnership innovations}

Partnerships, such as ones forged between public and academic libraries, are a major source of innovation since it promotes the sharing of expertise of different types of libraries. In the climate of shrinking budgets, the collaboration among public libraries, their branches, and community organizations allows greater expansion for public library patron services and better exposure within the community (Evjen, 2016). We define "Partnership" innovation as a novel integration of resources such as people and information, which are contributed or shared by organizations or units within a single organization. This study identified two subcategories of Partnership innovations: internal and external innovations. 
Internal Partnership innovations are found in large-scale public libraries with multiple branches and a myriad of functional units. One of our respondents implements this innovation.

15. Makerspace Task Force: Involving representatives from different functional units of a library, staff members bring different skills and expertise to build, manage, and sustain makerspace initiatives in their organization. Staff from functional units such as management and administration, reference services, technology, children and young adults, outreach and engagement can coordinate to design and operate an innovative makerspace for myriad of user populations.

External Partnership innovations mainly involve collaboration among different types of libraries and non-library stakeholders including but not limited to government agencies, schools, non-government organizations, local businesses, and patrons. One or more respondents reported the following examples in this sub-category of innovations.

16. College/Public Library Shared Campus Partnership: This partnership allows academic and public libraries to share the same physical space. As costs are cut, the increased collaboration is beneficial for organizations and patrons alike.

Collaborative resource access for multiple organizations is greater than just one organization going it alone.

17. Neighborhood Research Service: This innovation moves librarians out of the library and into local organizations, thereby creating collaboration and partnerships with community and county organizations to provide specialized services. Specifically, the librarians assist government officials by providing concentrated reference help as government officials work towards financial, programming, and other goals for the local community. These services remind government officials of the role that 
librarians play in helping people find resources that make a difference, and in this case, assist the government towards common goals.

18. Community Writing Project: It develops the collection of the library by allowing local authors to submit their publications for inclusion in the library. Selected winners have their books added to the online book depository, which has 4,000 hits daily.

19. School Access Program: This innovation allows local students to use their student ID cards (instead of a separate library card) to access library research tools and check out as many as ten books, DVDs, and other library resources for their personal use. This innovation increases student use of the public library and fosters collaboration between the library and local schools.

20. Digital Inclusion Week: It is a national-level effort to bring awareness of the digital inequalities in our society. Every summer, throughout the digital inclusion week, notfor-profit organizations across the nation participate in offering programs and events that highlight digital inclusion needs and work in our society.

\section{Technology innovations}

We cover technology products as part of this innovation category. Sometimes library administrators equate the term innovation with technologies that can help libraries attract and retain patrons (Knox, 2012). We define "Technology" innovation as a new initiative or procedure driven by or centered on the features and capabilities of a specific or a combination of technologies. Innovations related to web, assistive technologies, and artificial intelligence are examples of Technology innovations implemented by one or more respondents. 
21. Web-based Technologies: Google Chromebooks are fast, app-based computers provide patrons with cutting edge resources that they may not have access to outside of the public library. Another web-related innovation identified by respondents is hotspot lending. Hotspots provide internet access in situations where there is not regular WiFi access. These tools could be useful in a number of situations, but particularly for low income people who may not be able to afford internet in their homes.

22. Assistive Technologies: Reading machines are designed for people with visual impairments, which allow them to better access information that might not be possible without this technology.

23. Artificial Intelligence: Some respondents use robots and other artificial intelligence to further automate services and free up human resources for more purposeful activities. An Automated Material Handling System, which, in one instance, enables automated check-in when an item is placed in the return drop, is an example of automation is allowing staff to focus more on patron interactions and high-level programming.

Technology innovations are increasingly important for public libraries in order to combat the digital and accessibility divides (Calvert, 2017), especially since bridging the gap for disadvantaged patrons remains an important role for public libraries (Dobransky and Hargittai, 2006).

\section{Making sense of four types of innovations in public libraries}

Program innovations in public libraries customize services to cater to the needs of specific populations instead of a one-size-fits-all approach. Program innovations that aim to facilitate access to information resources and services to new patron segments not served by these 
libraries before, exemplifies expansionary innovations in voluntary and community organizations (Osborne, 1998). A majority of these Program innovations remove the barriers to accessing and using a wide range of resources and services, thereby creating a more inclusive society for traditionally marginalized populations. Providing access to and use of services and products are the main goals of program innovations in public libraries (Ralli and Payne 2016).

However, access to resources and services does not guarantee their use by patrons, hence to manage program innovations, librarians need to update their skills for helping patrons use the wide range of services and resources (Potnis, Regenstreif-Harms, Deosthali, Cortez, and Allard, 2016). To create a more welcoming atmosphere in libraries, librarians also need to be sensitive to the needs, expectations, and sociocultural differences among different marginalized populations (Cooke, 2017). Use-oriented Program innovations, which train and educate patrons for building new skills and knowledge or improving existing skills and knowledge, require the repositioning of approach and resources of public libraries, and hence, represent position innovations defined for organizations (Tidd, Bessant, and Pavitt 2013).

The outcome of Process innovations is mainly creating effectiveness and efficiency in ways in which public libraries serve patrons (Sin and Vakkari, 2015; Stejskal and Hajek, 2015). Efficiency-driven Process innovations represent continuous innovations (Robertson 1967) in public libraries since they aim to: (a) encourage crowdsourcing of ideas and equitydriven, bottom-up innovations in libraries, (b) create efficiency in the existing business processes of libraries, and (c) devise new program assessment and evaluation techniques. For instance, "Seed Grants for Supporting New Ideas by Library Staff' is a process innovation that is open to library staff seeking support for a project, program, or service enhancement. 
This innovation engages library staff in developing new programs or services for the library. The process provides bottom-up development and introduces ideas that might not have been previously considered. Over 100 ideas have come out of this innovation, such as lending musical instruments, grassroots staff mentoring, convening a social justice symposium for teens, pop-up STEM, as well as culinary literacy programs for children, lending custom family literacy packs, and library-wide programming for Pride month, among others.

In contrast, effectiveness-driven Process innovations mainly focus on responding to the external factors like the changing demographics of patrons and their needs, thereby increasing the effectiveness of the outreach and engagement activities by libraries. Process innovations in this sub-category represent the new ways created and delivered by public libraries for effectively serving patrons; hence, effectiveness-driven Process innovations match with the process innovations category defined by Tidd, Bessant, and Pavitt (2013).

Internal partnerships in public libraries are likely to enhance their operational excellence, and hence, they belong to the innovations in the operational excellence zone (Moore 2008). Internal partnerships need to be consistently monitored and guided by topadministrators in the libraries. Setting up key performance indicators and accountability would help these partnerships sustain in the long run.

External partnerships enable public libraries to serve new patrons with existing services; hence, this subcategory of Partnership innovation falls under the expansionary type of innovation proposed by Osborne (1998) for voluntary and community organizations. External partnerships can enhance perceived image of libraries in the public, creating more support for external funding for libraries. Partnerships can be formed and sustained only if they are synergistic and symbiotic, i.e., creating ongoing value for all the stakeholders 
involved in innovations (Giesecke, 2012). Sometime innovations in public libraries are driven by need. For instance, public libraries working in consortia require more interoperability, requiring new technology to serve that demand (Breeding, 2013). Library Technical Service Consortium, an innovation reported by a survey respondent, is a thirdparty technical service partnership of two major urban public libraries, which enhances the technical service capacity in a cost-effective manner. Book buying and collection management for both large libraries is carried out of a single facility, thereby saving money for the city they serve. Communication skills of leaders and representatives of organizations and their ability to create value for their core group of patrons seem to be the key for building these partnerships.

Technology innovations identified in this study fall under discontinuous innovation (Robertson, 1967) and evolutionary innovation category (Osborne, 1998), since libraries offer new services or implement new third-party technology-based products requiring patrons to change their behavior for receiving library and information service in new ways. Technology innovations act as a means to help libraries provide access to and use of their services and resources to all types of patrons with better speed and efficiency. However, libraries need to take into consideration the one-time investment cost and recurring operational costs before investing in these technologies, such as training librarians for using cutting-edge technologies. Technology skills are important to design, deploy, or maintain technology innovations in public libraries. Considering the rising popularity of mobile technologies and mobile apps, public libraries need to invest in mobile apps and related technologies for creating user-centered ubiquitous services (Potnis, Regenstreif-Harms, and Cortez, 2016). Updating to new versions of technologies and training of staff for using those 
technologies to serve the patrons represent some of the ongoing costs associated with technology-related innovations (King, 2018).

Libraries need to carefully assess and select technologies that help them achieve goals and vision. Aligning technologies with the library goal and vision is critical for benefitting from the technology implementation. It is not enough to provide access to patrons using cutting-edge technology innovations. Libraries are also responsible for keeping their patrons safe and secure when they use technology innovations offered by libraries. For instance, libraries should invest in appropriate security measures when creating hotspots, which would prevent data breaches and ensure patron privacy and security of information. Technology innovations not only help patrons, but also libraries. For instance, innovations like artificial intelligence free up limited human resources for purposeful activities. Thus, technology innovations in urban public libraries seem to create value for their internal and external stakeholders.

Sample applications of our findings are as follows.

1. Public libraries can apply our classification for managing a wide range of innovations. For instance, while undertaking Program innovations public libraries would need to first identify the target patron population they would like to serve, and then, identify and categorize their needs into two sub-categories, namely, access to and use of library and information services and resources valued by the target patron population. Finally, libraries can design their programs to help the target population access and/or use certain types of services and resources.

2. Innovations reported in this paper can inform public libraries interested in implementing any type of contemporary innovation. For instance, to improve operational efficiency, public libraries can gather more information about the 
efficiency-driven Process innovations discussed in this paper to assess the fit and learn from them.

3. Our classification underlines the significance of recruiting and training staff with the skills and knowledge needed to manage innovations. For instance, to implement technology innovations, libraries can recruit technology consultants equipped with the competencies needed to help libraries plan, assess, design, and implement technology innovations (Potnis and Allard, 2018).

\section{Theoretical Contribution}

Findings sharpen the typologies of innovations proposed by the past research, which is the unique theoretical contribution of this study. The existing typologies of innovations, which are depicted in Figure I above, do not include the sub-categories identified in this study. For instance, although Process has been identified as a type of innovation by the past research (e.g., Tidd, Bessant, and Pavitt, 2013) there is no sub-categorization of this innovation available in the literature; we advance this classification by identifying efficiency-driven and effectiveness-driven innovations. Also, access- and use-oriented innovations proposed by this study enrich the Program innovation defined by Rubin, Gavin, and Kamal (2011). Past research (e.g., Damanpour, 1996; Deft and Becker, 1978; Jantz 2012b) also does not establish sub-categories of technological or technical innovations in organizations. We fill in this gap by proposing three sub-categories of technological innovations in libraries.

\section{Conclusion, limitations, and future research}

Our proposed classification of innovations does not map "as is" onto any of the existing classifications of innovations rooted in private (e.g., Robertson, 1967; Dewar and Dutton, 1986; Tidd, Bessant, and Pavitt, 2013) or public (e.g., Baker, 2004; Osborne, Chew, and 
McLaughlin, 2008; Vassilakaki, 2015) sector organizations. This fact suggests a unique perspective of administrators of public libraries toward innovations and underlines the need and significance of the proposed classification of innovations for advancing our understanding of distinct types of innovations in public libraries.

Much of the existing guidance for administrators to manage innovations is dedicated to the big picture such as effectuating change and talent management (Dewey, 2012), knowledge management (Bossaller, Adkins, and Brendler, 2017), and encouraging innovation (Maness and Culshaw, 2015) within libraries. There is scarce information related to the decision factors and actual activities administrators can undertake for fostering innovations (Ippoliti, 2016). Our proposed classification of contemporary innovations in four clusters can serve as an effective tool for public libraries, especially for small and rural public libraries, which might not have the necessary expertise to make sense of the environmental scan of innovations in other libraries. For instance, public libraries interested in responding to opportunities or pressures by introducing innovations can skim through the distinct innovations reported by award-winning public libraries in this study; learn our interpretation of these innovations, which is grounded in the literature on managing innovations; and finally, assess the compatibility of these innovations, before committing to and investing in any specific innovation.

Some of the innovations reported by study participants, which they are also proud of, might not seem particularly innovative because they were introduced 8-10 years ago and nowadays several libraries undertake these initiatives. The fact that administrators of public libraries consider some commonly implemented initiatives as "innovative" sheds light on the perception of administrators of award-winning public libraries toward innovations. We recommend library administrators to continuously update their understanding of what is 
innovative by periodically conducting a thorough environmental scan to learn what other public libraries are doing to better serve patrons.

\section{Limitations \& Future Research}

Due to a limited budget, this study focused on public libraries in the United States alone. Findings are based on self-reported responses by administrators of a small percentage of award-winning public libraries in the United States, which do not necessarily represent the innovations in all public libraries in the region. In the future, to validate the classification proposed in this paper, one can ask library administrators to classify their existing innovations using our classification and seek feedback on the utility of this classification for managing innovations. We plan to interview study participants to learn what made these initiatives innovative when they were launched in the distant past. It is important to note that the proposed classification scheme might not be useful unless management style and culture of the public library change. Hence, in the future, we plan to study challenges to incorporating the proposed classification in the strategic planning and management of innovations in public libraries. Our classification of innovations can be tested using innovations in different types of library settings to check its applicability and value for academic, special, and school libraries. Finally, our proposed classification would also be useful to check if libraries are engaging in different types of innovations, their motivation and challenges to implementing innovations, and identify the correlation, if any, between the type of libraries and the type of innovations. The future research inquiry along this line could lead to identifying and mapping a cluster of challenges on the type of innovations, which would help libraries better plan and implement innovations. 


\section{Acknowledgement}

We are thankful to the Dean of College of Communication and Information at the

University of Tennessee at Knoxville for funding this research project.

\section{References}

American Library Association (2001) Library services for people with disabilities policy. Available at: http://www.ala.org/ala/ascla/asclaissues/libraryservices.cfm (accessed 29 May 2019).

Anderson S (2003) The place to go: The 135th street branch library and the Harlem renaissance. Library Quarterly 73(4): 383-421.

Auerbach, C and Silverstein L (2003) Qualitative Data: An Introduction to Coding and Analysis. New York: University Press.

Baker D (2004) The Strategic Management of Technology: A Guide for Library and Information Services. Oxford: Chandos.

Baker D (2014) Resource discovery and delivery: Back to the future. Interlending and Document Supply 42(4): 144-146.

Baker D (2016) Making sure things can never be the same again: Innovation in library and information services. Innovation and Libraries and Information Services 35(1): 1-44.

Baregheh A, Jennifer R and Sambrook S (2009) Towards a multidisciplinary definition of innovation. Management Decision 47(8): 1323-1339.

Bertot J, Paul J, Lee J, Dubbels K, McDermott A and Real B (2014) 2013 Digital inclusion survey. Available at: http://digitalinclusion.umd.edu (accessed 29 July 2018).

Bossaller J, Adkins, D and Brendler B (2017) Learning to lead: Challenges and resources for the new public library director. Journal of Library Administration 57(1): 444-460.

Breeding M (2013) Observations, trends, and ongoing challenges. Library Technology Reports 49(1): 32-33.

Brundy C (2015) Academic libraries and innovation: A literature review. Journal of Library Innovation 6(1): 22.

Calvert P (2017) Robots, the quiet workers, are you ready to take over? Public Library Quarterly 36(2): 167-172. 
Campbell J, Quincy C, Osserman J and Pedersen O (2013) Coding in-depth semistructured interviews: Problems of unitization and intercoder reliability agreement. Sociological Methods \& Research 42(3): 294-320.

Carpenter M and Green R (2009) Managing library 2.0. Journal of Access Services 6(1): 158-162.

Civitello A (2017) Libraries, innovation, and literacy. Public Libraries 56(6): 9-10.

Conway N (2005) To what extent does the Bookstart scheme affect the role of the public librarian? PhD Thesis, University of Sheffield, UK.

Cooke N (2017) Information services to diverse populations: Developing culturally competent library professionals. Santa Barbara, CA: Libraries Unlimited.

Daft R and Becker S (1978) Innovation in organizations, New York: Elsevier.

Dain P (1972) The New York public library: A bistory of its founding and early years. New York: New York Public Library.

Damanpour F (1996) Organizational complexity and innovation: Developing and testing multiple contingency models. Management Science 42(2): 693-716.

Damanpour F and Schneider M (2008) Characteristics of innovation and innovation adoption in public organizations: Assessing the role of managers. Journal of Public Administration Research and Theory 19(3): 495-522.

Dewar R and Dutton J (1986) The adoption of radical and incremental innovations: An empirical analysis. Management Science 32(11): 1422-1433.

Dewey B (2012) In transition: The special nature of leadership change. Journal of Library Administration 52(1): 133-144.

Dobransky K and Hargittai E (2006) The disability divide in Internet access and use. Information, Communication \& Society 9(3): 313-334.

Evans J, Ward P and Rugaas B (2000) Management basics for information professionals. New York: Neal-Schuman Publishers Inc."

Evjen S (2015) The image of an institution: Politicians and the urban library project. Library \& Information Science Research 37(1): 28-35.

Farkas M (2010) Nurturing innovation. Available at: http:/ / americanlibrariesmagazine.org (accessed 25 December 2018)

Field N and Tran R (2018) Reinventing the public value of libraries. Public Library Quarterly. Epub ahead of print 11 January 2018. DOI: 10.1080/01616846.2017.1422174.. 
Freeburg D (2018) Leadership and innovation within a complex adaptive system: Public libraries. Journal of Librarianship and Information Science. Epub ahead of print 19 November 2018. DOI: $\underline{10.1177 / 0961000618810367 . .}$

Henkel M, Ilhan A, Mainka A, and Stock W (2018) Open innovation in libraries. In 51st Hawaii International Conference on System Sciences, Waikoloa Village, Hawaii, 2-6 January 2018, pp. 4151-4160, Red Hook: Curran Associates, Inc.

Giesecke, J (2012) The value of partnerships: Building new partnerships for success. Journal of Library Administration 52(1): 36-52.

Gorham U and Bertot J (2018) Social innovation in public libraries: Solving community challenges. Library Quarterly 88(3): 203-207.

Goulding A and Walton G (2014) Distributed leadership and library service innovation. In: Woodsworth A and Penniman W (eds.) Advances in Librarianship. Bingley: Emerald Group Publishing Limited, pp. 37-81.

Ippoliti C (2016) From zero to sixty in under one year: A practical approach to building new programs and services, managing change, and embracing innovation as a new library administrator. Library Leadership \& Management 31(1): 1-20.

Jantz R (2012a) A framework for studying organizational innovation in research libraries. College and Research Libraries 73(6): 525-541.

Jantz R (2012b) Innovations in academic libraries: An analysis of university librarians' perspective. Library and Information Science Research 34(1): 3-12.

Jantz R (2013) Incremental and radical innovations in research libraries: An exploratory examination regarding the effects of ambidexterity, organizational structure, leadership, and contextual factors. PhD Thesis, Rutgers University, USA.

Jenkins B (1990) A white librarian in black Harlem: Study to chronicle and assess Ernestine Rose's work during the renaissance in Harlem. Library Quarterly 60(3): 216-231.

King D (2018) How to stay on top of emerging technology trends for libraries. Library Technology Reports 54(2): 1-35.

Knab S (2010) Comments from the Editor-in-Chief. Journal of Library Innovation 1(1):3-5.

Knox K (2012) Innovations about at PLA 2012. Information Today 29(5): 23.

Koizumi M and Widdersheim M (2016) Surpassing the business model: A public sphere approach to public library management. Library Review 65(6/7): 404-419. 
Mathews, B (2012) Think like a startup: A white paper to inspire library entrepreneurialism. Available at: https://vtechworks.lib.vt.edu/handle/10919/18649 (accessed 14 November 2018)

Matthews J (2017) Facing the digital reality. Public Library Quarterly 36(2): 95.

Maness J and Culshaw J (2015) Reorganizing for transformational change: The 21st century research library at a flagship public university. Library Leadership \& Management 29(1): 1-29.

Moore G (2008) Dealing with Darwin: How Great Companies Innovate at Every Phase of Their Evolution. Penguin Group, New York: NY.Nadler D and Tushman M (1990) Beyond the charismatic leader: Leadership and organizational change. California Management Review 32(1): 77-97.

Osborne S (1998) The innovative capacity of voluntary organisations. Managerial challenges for local government. Local Government Studies 24(1): 19-40.

Osborne S, Chew, C and McLaughlin K (2008) The once and future pioneers? The innovative capacity of voluntary organisations and the provision of public services: A longitudinal approach. Public Management Review 10(1): 51-70.

Oxford English Dictionary Online (2018) “innovation, n.” Oxford University Press. Available at: http://www.oed.com.proxy.lib.utk.edu:90/view/Entry/96311?redirectedFrom=innovation (accessed 30 April 2018)

Potnis D (2010). Measuring e-Governance as an innovation in the public sector. Government Information Quarterly 27(1): 41-48.

Potnis D, Regenstreif-Harms R, Deosthali K, Cortez E and Allard S (2016) Skills and knowledge needed to serve as mobile technology consultants in information organizations. Journal of Education for Library and Information Science 57(2): 187-196.

Potnis D, Regenstreif-Harms R and Cortez E (2016). Identifying key steps for developing mobile applications \& mobile websites for libraries. Information Technologies and Libraries 35(3): 40-58.

Potnis D and Allard S (2018) Training LIS students as mobile technology consultants for libraries and not-for-profit organizations. Journal of Education for Library and Information Science 59(4): 253-264.

Pulido M, Pulido P and Vivarelli M (2016) The Identity of the Contemporary Public Library: Principles and Methods of Analysis, Evaluation, Interpretation. Milan: Ledizioni Ledi Publishing.

Pungitore V (1995) Innovation and the Library: The Adoption of New Ideas in Public Libraries. Westport: Greenwood Press. 
Ralli J and Payne R (2016) Let's play at the library: Creating innovative play experiences for babies and toddlers. Library Trends 65(1): 41-64.

Robertson T (1967) The process of innovation and the diffusion of innovation. Journal of Marketing 31(1):14-19.

Rowley J (2011) Should your library have an innovation strategy? Library Management 32(4/5): 251-265.

Rowley J, Baregheh A and Sambrook S (2011) Towards an innovation-type mapping tool. Management Decision 49(1): 73-86.

Rubin V, Gavin P and Kamal A (2011) Innovation in public and academic North American libraries: Examining white literature and website applications. Canadian Journal of Information and Library Science 35(4): 397-422.

Schumpeter J (1939) Business Cycles: A Theoretical, Historical, and Statistical Analysis of the Capitalist Process. New York: McGraw-Hill Book Company.

Sin S and Vakkari P (2015) Perceived outcomes of public libraries in the U.S. Library \& Information Science Research 37(1): 209-219.

Skinner J (2017) Innovation in Harlem: Using the change in historic institutions model to study a public library's development. Library Quarterly 87(2): 136-149.

Stejskal J and Hajek P (2015) Effectiveness of digital library services as a basis for decisionmaking in public organizations. Library \& Information Science Research 37(4): 346-352.

Thorpe C (2017) Engaging with our communities: Future trends and opportunities for reference services. Journal of the Australian Library \& Information Association 66(4): 406-415.

Tidd J, Bessant J and Pavitt K (2013) Managing Innovation. Hoboken: Wiley.

Urban Libraries Council (2018) Innovations Initiative. Available at:

https://www.urbanlibraries.org/innovations (accessed 3 November 2018)

Vassilakaki E (2015) Knowing your users, Discovering your library: An overview of the characteristics of user generations. In: Baker D and Evans W (eds) Digital Information Strategies: From Applications and Content to Libraries and People. Oxford: Chandos, pp. 215-224.

Yeh S and Walter Z (2017) Determinants of service innovation in academic libraries through the lens of disruptive innovation. College \& Research Libraries 77(6): 1-10.

Widdersheim M (2015) Governance, legitimation, commons: A public sphere framework and research agenda for the public library sector. Libri 65(4): 237-245. 